\title{
Treatment for Functioning Pituitary Adenomas
}

\author{
Masamichi Kurosaki, M.D. \\ Division of Neurosurgery, Department of Brain and Neurosciences, Faculty of Medicine, Tottori University
}

There are three therapeutic modes available for management of functioning pituitary adenomas, including surgery, medical treatment, and irradiation. Transsphenoidal surgery (TSS) is the gold standard for the surgical treatment. And as consequently, endoscopic TSS has been recently introduced into many institutes.

1) Growth hormone (GH) - producing pituitary adenoma (acromegaly, gigantism)

Transsphenoidal surgery is the first-choice treatment for acromegaly. Unless the patients have achieved a nadir GH level of $<0.4 \mathrm{ng} / \mathrm{m} l$ after a glucose load or their normal IGF-1 levels, medical and/or radiation therapy should be considered. Dopamine agonists, somatostatin analogues, or GH antagonists has been the popular options for the medical therapy.

2 ) Prolactin (PRL)-producing pituitary adenoma

Cabergoline in preference to other dopamine agonists is the treatment of choice for prolactinomas, because of its efficacy in normalizing PRL levels, and inducing tumor shrinkage. However the potential development of cerebrospinal fluid rhinorrhea and meningitis should be carefully monitored following the treatment with cabergoline. Actually the value of high-dose cabergoline treatment for the resistant cases has been reported. Women with prolactinomas should be instructed to discontinue cabergoline therapy as soon as they discover that they are pregnant. It is also prudent to require more frequent clinical examinations including visual field testing because there is a concern that macroprolactinomas may grow during pregnancy.

3 ) Adrenocorticotropic hormone (ACTH) -producing adenoma (Cushing's disease)

TSS is the first-choice treatment for Cushing's disease. The selective sampling obtained directly from the cavernous sinus provides information helpful for the precise tumor localization in minute adenoma cases. Unfortunately no medical treatment has ever been available for curing patients. However, stereotactic radiation therapy typically using a gamma knife is effective for refractory cases.

(Received Januany 9, 2018; accepted February 6, 2018)

Key words : pituitary adenoma, transsphenoidal surgery, acromegaly, prolactinoma, Cushing's disease Jpn J Neurosurg（Tokyo）27:449-455, 2018 


\section{はじめに}

脳腫瘍全国集計（1984～2000 年）によれば，下垂体腺 腫は原発性脳腫瘍の $18 \%$ を占め, 頻度としては, 神経膠 腫, 髄膜腫に次ぎ 3 番目に多い ${ }^{5)}$. 臨床上は, プロラク チン（PRL）産生腺腫（25\%), 成長ホルモン $(\mathrm{GH})$ 産 生腺腫 $(22 \%)$, 副腎皮質刺激ホルモン (ACTH) 産生腺 腫（6\%), 甲状腺刺激ホルモン（TSH）産生腺腫（1\%） の機能性腺腫と非機能性腺腫（46\%）に大別される。機 能性下垂体腺腫の治療法としては手術, 薬物, 放射線治 療があるが，PRL 産生腺腫以外は，手術（経鼻的経蝶形
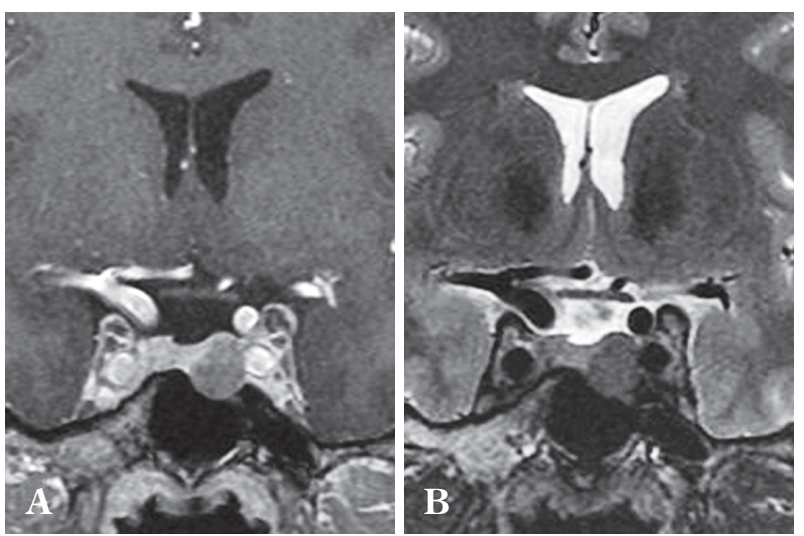

Fig. 1 Coronal-postcontrast T1-weighted (A), and T2-weighted (B), 3 T MR images of the sellar region of a $42^{-}$year-old man with a $\mathrm{GH}^{-}$ producing pituitary adenoma.

A : The adenoma is depicted clearly as a less enhanced area.

B : The adenoma is clearly visible as a hypointense mass.
骨洞手術：TSS）が第一選択となる。本稿では，機能性 下垂体腺腫のうち，主に GH 産生腺腫，PRL 産生腺腫， $\mathrm{ACTH}$ 産生腺腫の治療について最近の知見を踏まえて概 説する。

\section{GH 産生腺腫（巨人症・先端巨大症）}

病理組織学的には, 細胞質内に分泌顆粒を豊富に有す る細胞から構成される densely granulated type と細胞質 内に分泌顆粒がそしく, fibrous body とよばれる特徵的な 細胞質内構造物を有する sparsely granulated type に大別 される。臨床的には，前者では，より高年に発症し，腫 瘍の成長速度が遅く, 頭部 MRI の T2 強調画像（WI）で 低信号を呈し（Fig. 1)，後者では若年発症，腫瘍の成長 速度が早い，浸潤性，難治性，T2WI で高信号を呈する といった特徵がある ${ }^{910) 39) . ~}$

治療の目的は, GH 分泌過剩に起因する症候の是正と, 合併症の罹患率減少を図り死亡率を一般人口の平均まで 引き下げるとともに腫瘍周辺正常組織の障害を軽減する ことにある ${ }^{36)}$ 。ニュージーランドの疫学調査によれば, 血中 $\mathrm{GH}$ 值が $1 \mathrm{ng} / \mathrm{m} l$ 未満または $\mathrm{IGF}-1$ 值を正常化する ことによって生存率は健康成人とほぼ同等になることが 示唆された ${ }^{11)}$ 。このエビデンスを基に, 1999 年にコルチ ナ（イタリア）で行われた国際会議で治癒基準が提唱さ れた ${ }^{8)}$ 。わが国においてもこれに準じて，厚生労働省間 脳下垂体機能障害に関する調査研究班によって策定され た「先端巨大症および下垂体性巨人症の診断と治療の手 引き」に，(臨床的活動性を示す徵候がまったくなく，ブ ドウ糖 $75 \mathrm{~g}$ 経口投与後の血中 $\mathrm{GH}$ 底值が $1 \mathrm{ng} / \mathrm{ml}$ 未満か

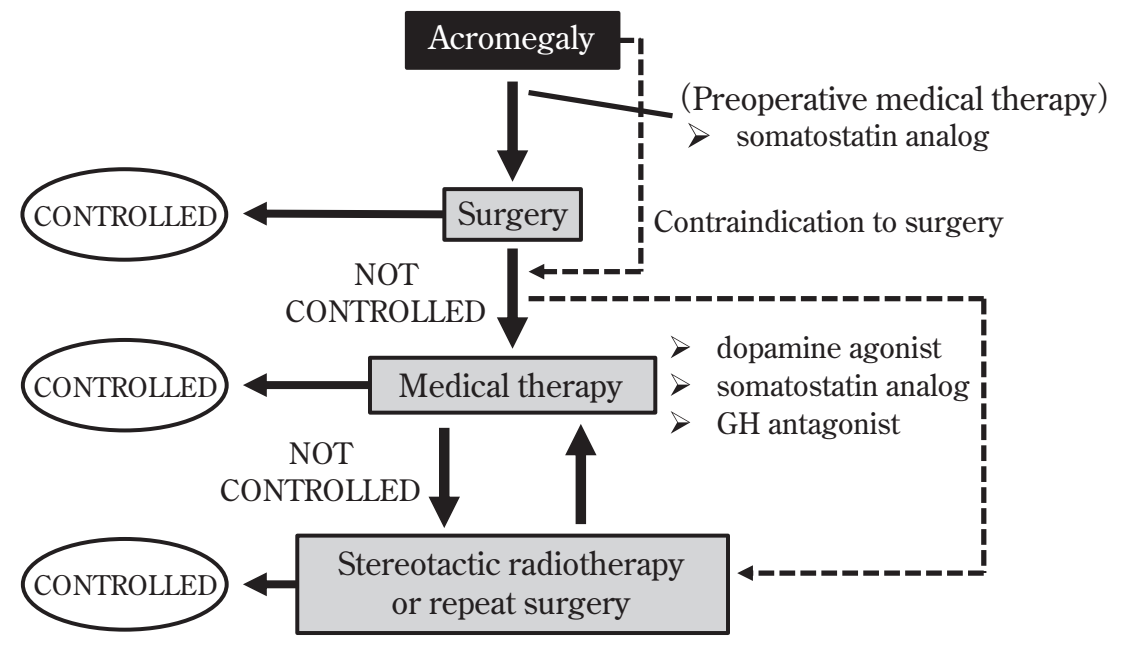

Fig. 2 Management of acromegaly Based on the reference ${ }^{20)}$ 
つ IGF-1 值が年齢・性別基準範囲内であること）と治癒 基準が定められた ${ }^{20)}$.

Fig. 2 で示すように，治療の第一選択は TSS である. 術後に前述の治癒基準を満たさないコントロール不十 分, 不良例に対しては, 薬物療法や主にガンマナイフを 用いた定位的放射線治療が行われる。上記の診断と治療 の手引きの平成 26 年度改訂版では, 治癒基準のブドウ 糖 $75 \mathrm{~g}$ 経口投与後の血中 $\mathrm{GH}$ 底值が $1 \mathrm{ng} / \mathrm{ml}$ から $0.4 \mathrm{ng} /$ $\mathrm{ml}$ に変更となり, さらに厳格となった。

手術では多くの場合，TSSが行わ机る，従来，下垂体 外科を専門とする施設での治癒率は $42 \sim 70 \%$ とされて いた ${ }^{28)}$. 手術による治癒が困難となる因子として, 術前 の血中 GH 值の高いもの, 腫瘍が大きいもの, 海綿静脈 洞への浸潤を示すものが挙げられる ${ }^{28)}$. Nishioka $~^{27)}$ は，海綿静脈洞浸潤部分に対しても積極的に摘出を行う ことにより，内分泌学的治癒率が $84.7 \%$ と非常に良好な 成績を報告している. また, 病理組織学的な pseudocapsule を意識したいわゆる被膜外摘出を行うことで治癒率 が向上するとされている ${ }^{14) 30)}$ ，最近では神経内視鏡を用 いた TSS が普及してきている. Starke ら ${ }^{38)}$ は, 熟練した 下垂体外科医が TSS を行った場合, 内視鏡手術あるいは 顕微鏡手術での内分泌学的治癒率に差はないと報告して いるが，最近では，海綿静脈洞浸潤を示さない macroadenoma では内視鏡手術のほうが，治癒率がよくなってい $3^{33)}$.

薬物療法では，ドパミン作動薬，ソマトスタチン誘導 体，GH 受容体拮抗薬が用いられる ${ }^{15) 20) 39)}$. ドパミン作 動薬は経口投与で，カベルゴリンが一般的に使われる （ただし，保険適用は高 PRL 血性下垂体腺腫に限る）。

ソマトスタチン誘導体（オクトレオチド，ランレオチ ド）は現在，内科治療の第一選択薬であり，約 6〜7 割の 患者で内分泌学的治癒が得られ, 約半数で腫瘍の縮小を 認める ${ }^{15) 20) 39)}$. 月 1 回投与の注射製剤の開発により, 治 療の受け入れやすさは格段に改善した。術前投与に関し ては，手術成績が向上するという報告もあるが，米国の ガイドラインでは routine で行う必要はないとされてい $3^{15)}$ 。喉頭浮腫や心機能障害による周術期のリスク軽減 のためには有用である.

最近では，T2WI の信号強度に基づいて追加薬剤を考 慮する治療法が提唱されている35)。すなわち，T2WIで 高信号（sparsely granulated type）症例はソマトスタチン 誘導体に対して薬剤抵抗性である可能性が高いため, $\mathrm{GH}$ 受容体拮抗薬の単独または併用療法を推奨すると いったものである ${ }^{35)}$ 。また, ソマトスタチン誘導体の新 しい薬であるパシレオチドが使用可能となり，これは従
来のソマトスタチン誘導体に比べて, ソマトスタチン受 容体 (SSTR) 5 との親和性が高く, sparsely granulated type に対する効果が期待されている ${ }^{6)}$.

通常の放射線治療では内分泌学的寬解率は 20 年で 70 90\% とされてきたが， GH が $5 \mathrm{ng} / \mathrm{ml}$ 以下の古い基 準によるものである ${ }^{23)}$. 照射後 10 年で何らかの下垂体機 能低下症が 80〜 90\%に出現するといわれている ${ }^{23)}$. 最近 の定位放射線治療，特にガンマナイフの治療成績とし て，より厳密な基準を適用した場合，寬解率は 17 ～50\% にとどまっている313131734)，通常の放射線治療と比べて 下垂体機能低下症の出現は少ない。視神経への照射を 8〜10 Gy 以下にすることが必須とされていたが22141), 最 近は視神経の一部であれば 10〜 $12 \mathrm{~Gy}$ 程度の照射は問題 ないとされている ${ }^{37)}$.

\section{PRL 産生腺腫}

高 PRL 血症を呈する疾患および病態としては, 非機能 性腺腫や他の間脳下垂体疾患, 薬物 (制吐薬・抗潰瘍薬, 向精神薬，降圧薬・循環器薬，エストロゲン製剤）服用 によるもの，原発性甲状腺機能低下症などが挙げられる ため, これらとの鑑別が必要である1924).

ドパミン作動薬を用いた薬物療法が第一選択であり, 大半の症例で PRL 值の有意な低下と腫瘍体積の減少が もたらされる $(\text { Fig. 3 })^{21)}$. ドパミン作動薬の中でも第一 選択は，カベルゴリンであり，PRL 血中濃度の正常化率 は, microadenoma で 81 96\%, macroadenoma で 61 $83 \%$, 腫瘍縮小率は 46〜89\% と報告されている ${ }^{19) 24) 31)}$.

カベルゴリンを高用量使用することにより，ブロモク リプチン抵抗症例でも良好な成績が得られるという報告 もある ${ }^{31} 32$. ドパミン作動薬服用中に妊娠が判明した場 合にはただちに中止するが，腫瘍の急性増悪をきたす可 能性があるので，PRL 值を経時的に測定する必要があ る ${ }^{19)}$ 。 カベルゴリンの副作用として，吐き気，胃部不快 感，便秘などといった消化器症状や起立性低血圧などが 知られている ${ }^{19) 24)}$ 。その他，抗 Parkinson 病薬として使 用した場合に心臟弁膜症を発症することが知られてい る. 1 日使用量 $3 \mathrm{mg}$ 以上で， 6 力月以上使用すると発症 率が高まるといわれており，PRL産生腺腫に対する通常 の使用量では発症の危険性は低いが，長期使用例では超 音波検査による定期的な心機能評価が必要である ${ }^{36)}$.

以下の場合は手術適応となる. (1)薬物療法で PRL值が 正常化しないもの, (2)大型腺腫で薬物療法により腫瘍径 の縮小しないもの，(3)副作用のため薬物療法を続けられ ないもの, (4)臨床的な下垂体卒中例, (5)薬物療法によっ 

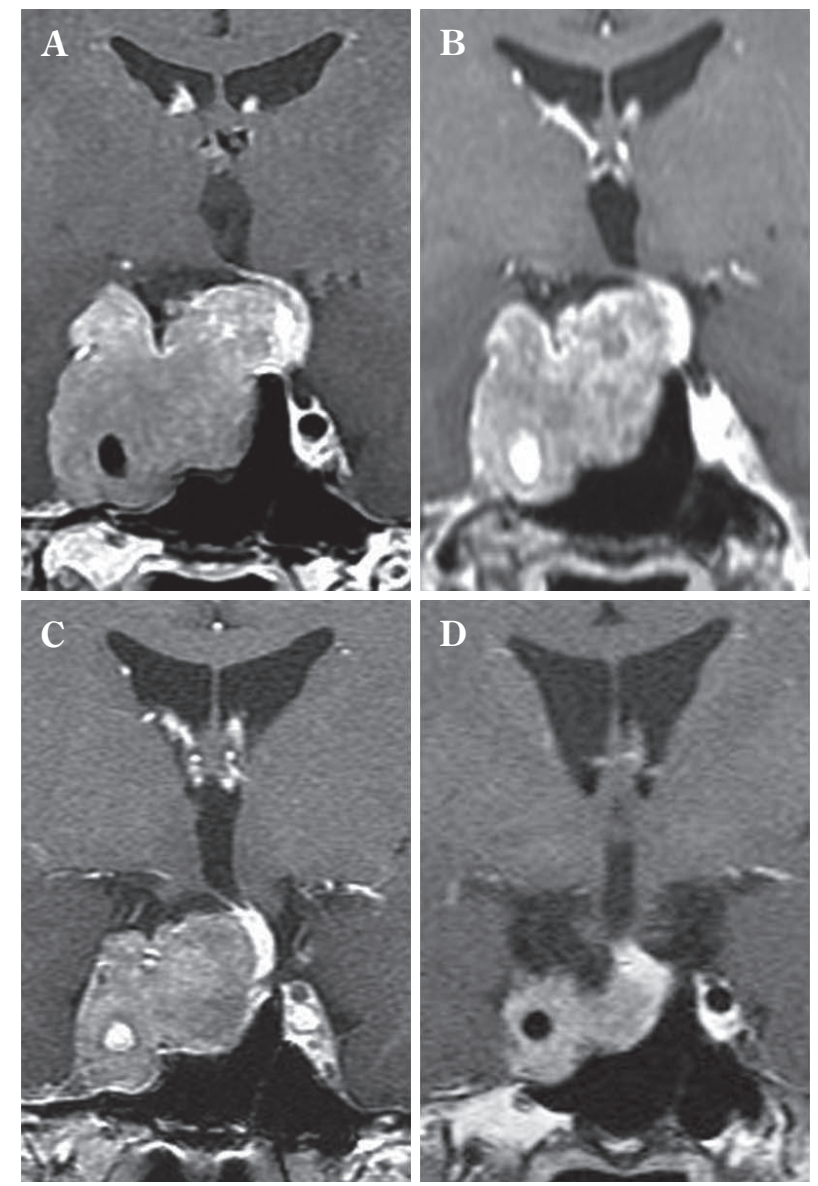

Fig. 3 Coronal-postcontrast T1-weighted $3 \mathrm{~T}$ MR images during cabergoline therapy

Tumor size has decreased considerably. Before therapy (A), at 2 months (B), at 4 months (C), and at 1 year $(\mathbf{D})$.

Adapted with permission from Kurosaki ${ }^{21)}$

て髄液漏をきたしたもの.

プロラクチン (PRL) 分泌過剩症の診断と治療の手引 きでは, macroprolactinoma の場合, ドパミン作動薬の効 果が不十分な場合には, 短期間で薬物を中止し, 手術に よって腫瘍容積を可及的に減じたうえで, 再度薬物療法 を行うことが推奨されている。 また，トルコ鞍内に限局 した非浸潤性の microprolactinoma の場合, 熟達した脳神 経外科医が手術すれば治癒する可能性が十分あることを 治療の選択肢として説明する必要があるとされている ${ }^{19)}$.

\section{ACTH 産生腺腫（Cushing 病）}

Cushing 症候群のうち, 下垂体腺腫からの ACTH の過 剩産生を原因とするものは Cushing 病と呼ばれる。診断 のフローチャートを Fig. 4 に示す．腺腫は小さなものが
多く，診断には選択的カテーテル操作を応用した海綿静 脈洞サンプリングも有用である ${ }^{40)}$. 未治療の 5 年生存率 は $50 \%$ と不良で, 死因は重症感染症, 心血管障害, 電解 質異常などである23)26)28).

治療に関しては TSS が第一選択である。術後 1 週間以 内の血中ACTH とコルチゾールが測定感度以下, $\mathrm{CRH}$ 試 験にて ACTH 無反応であれば, ほとんどの例で治癒に至 る. Microadenoma の手術による宽解は 86〜98\% と良好 であるが，浸潤性 macroadenoma での長期宽解率は 31 83\% と低くなっている ${ }^{18) 26) 29)}$ ．治癒に至った例では，七 ドロコルチゾンを生理量補充し, 6 力月～ 2 年で漸減, 中 止する，術後の ACTH，コルチゾールの低下が正常域に とどまる場合は，治癒に至らず再燃する例が多いため， 注意深い観察が必要である。

薬物療法に関しては, 直接 ACTH 分泌を抑制するシプ ロヘプタジン，バルプロ酸，ドパミン作動薬，ソマトス タチン誘導体やステロイド合成阻害剤としてトリロスタ ン，ミトタン，メチラポンなどが使用されるが，いずれ も有効率は低い ${ }^{18) 26) 29)}$ 。近年, SSTR5 とSSTR2 に親和 性の高いパシレオチドは Cushing 病に対しても有効性が 期待されている1).

治療困難例では放射線治療が用いられる，従来，放射 線治療では内分泌学的寛解率は $3 \sim 5$ 年で $50 \sim 60 \%$ とさ れてきた ${ }^{2)}$ 。ガンマナイフ治療はホルモン抑制効果，腫 瘍抑制効果ともに機能性腺腫の中では，ACTH 産生腺腫 に対して高いとされている。.内分泌学的寬解率は 17〜 $83 \%$ と報告されているが7 12)16)42)，治癒基準や経過観察 期間が施設によりさまざまである点が問題となっている.

摘出組織の正常部分には Crooke 変性細胞（高コルチ ゾール血症で negative feedback がかかり, 正常 ACTH 細 胞が keratin で満たされた丸い細胞に変性する)がみられ る. ACTH 陽性細胞が Crooke 変性細胞のようにみえる Crooke cell adenoma は ACTH 産生腺腫の variant であり, 浸潤性で macroadenomaであり, aggressive な特徴をもつ ため，初回治療で良好な結果が得られても，注意深い経 過観察が必要である ${ }^{425)}$.

\section{おわりに}

機能性下垂体腺腫の治療について, 最近の話題も含め て解説した。今後, $3 \mathrm{D}$ 内視鏡システムや $4 \mathrm{~K}$ 技術搭載内 視鏡システムの普及に伴い，TSS における内視鏡手術の さらなる発展が期待される。 また，拡大 TSS や経鼻開頭 同時手術の応用により，手術適応が広がると思われる が，その一方，合併症を回避するためには限界を知るこ 
The first-line screening

ACTH, cortisol : high normal

Urine free cortisol $:$ high $\sim$ normal

$0.5 \mathrm{mg}$ overnight dexamethasone suppression test : $\operatorname{cortisol} \geq 5 \mu \mathrm{g} / \mathrm{d} l$

Desmopressin test : $\mathrm{ACTH} \geq 1.5$ fold

The second-line screening

CRH test : ACTH $\geq 1.5$ fold

$8 \mathrm{mg}$ overnight dexamethasone suppression test : cortisol $\leq 50 \%$

Pituitary MRI

Selective cavernous sinus sampling

Central/peripheral gradient of $\mathrm{ACTH} \geq 2$

$[<2 ;$ ectopic ACTH syndrome $(\mathrm{s} / \mathrm{o})]$

$\mathrm{CRH}$ : corticotropin releasing hormone

Cushing's disease

Fig. 4 Pathways to the diagnosis of Cushing's disease

とも必要である。機能性下垂体腺腫の場合は腫瘍制御の

みならず内分泌学的寛解を得ることが重要であるため, 海綿静脈洞浸潤症例や男性 PRL 産生腺腫例, GH 産生腺

腫の sparsely granulated type, Crooke cell adenoma などの aggressive behavior ${ }^{4}$ を呈する症例に対して，手術以外の option（薬物治療，放射線治療）を組み合わせた最適な 複合的治療を行うことが必要である.

COI の開示 : 著者は日本脳神経外科学会への COI 自己登録 を完了しています。本論文において開示すべき COI はありま せん.

\section{文 献}

1) Arnaldi G, Polenta B, Cardinaletti M, Boscaro M : Potential indications for somatostatin analogs in Cushing's syndrome. J Endocrinol Invest 28 (11 Suppl International) : 106-110, 2005.

2) Biller BM, Grossman AB, Stewart PM, Melmed S, Bertagna X, Bertherat J, Buchfelder M, Colao A, Hermus AR, Hofland LJ, Klibanski A, Lacroix A, Lindsay JR, Newell-Price J, Nieman LK, Petersenn S, Sonino N, Stalla GK, Swearingen B,
Vance ML, Wass JA, Boscaro M : Treatment of adrenocorticotropin-dependent Cushing's syndrome: a consensus statement. J Clin Endocrinol Metab 90 : 2454-2462, 2008.

3) Castinetti F, Taieb D, Kuhn JM, Chanson P, Tamura M, Jaquet P, Conte-Devolx B, Régis J, Dufour H, Brue T : Outcome of gamma knife radiosurgery in 82 patients with acromegaly : correlation with initial hypersecretion. J Clin Endocrinol Metab 90: 4483-4488, 2005.

4) Chatzellis E, Alexandraki KI, Androulakis II, Kaltsas G : Aggressive pituitary tumors. Neuroendocrinology 101:87104, 2015.

5) Committee of Brain Tumor Registry of Japan : Report of Brain Tumor Registry of Japan (1984-2000). Neurol Med Chir (Tokyo) 49 Suppl: PS1-96, 2009.

6) Cuevas-Ramos D, Fleseriu M : Pasireotide: a novel treatment for patients with acromegaly. Drug Des Devel Ther 10:227-239, 2016.

7) Estrada J, Boronat M, Mielgo M, Magallón R, Millan I, Dez S, Lucas T, Baceló B: The long-term outcome of pituitary irradiation after unsuccessful transsphenoidal surgery in Cushing's disease. N Engl J Med 336 : 172-177, 1997.

8) Giustina A, Barkan A, Casanueva FF, Cavagnini F, Frohman L, Ho K, Veldhuis J, Wass J, Von Werder K, Melmed S : Criteria for cure of acromegaly: a consensus statement. J Clin Endocrinol Metab 85:526-529, 2000.

9) Hagiwara A, Inoue Y, Wakasa K, Haba T, Tashiro T, Miya- 
moto $\mathrm{T}$ : Comparison of growth hormone-producing and non-growth hormone-producing pituitary adenomas : imaging characteristics and pathologic correlation. Radiology 228: 533-538, 2003.

10) Heck A, Emblem KE, Casar-Borota O, Bollerslev J, Ringstad $\mathrm{G}$ : Quantitative analyses of $\mathrm{T} 2{ }^{-}$-weighted MRI as a potential marker for response to somatostatin analogs in newly diagnosed aromegaly. Endocrine $\quad \mathbf{5 2}: 333-343,2016$.

11) Holdaway IM, Rajasoorya RC, Gamble GD : Factors influencing mortality in acromegaly. J Clin Endocrinol Metab 89: 667-674, 2004 .

12) Jagannathan J, Sheehan JP, Pouratian N, Laws ER, Steiner L, Vance ML : Gamma knife radiosurgery for Cushing's disease. J Neurosurg 106:980-987, 2007.

13) Jagannathan J, Sheehan JP, Pouratian N, Laws ER Jr, Steiner L, Vance ML: Gamma knife radiosurgery for acromegaly : outcomes after failed transsphenoidal surgery. Neurosurgery 62: 1262-1269, 2008 .

14) Kawamata $T$, Kubo O, Hori $T$ : Surgical removal of growth hormone-secreting pituitary adenomas with intensive microsurgical pseudocapsule resection results in complete remission of acromegaly. Neurosurg Rev 28:201-208, 2005.

15) Katznelson L, Laws ER Jr, Melmed S, Molitch ME, Murad MH, Utz A, Wass JA ; Endocrine Society: Acromegaly : an endocrine society clinical practice guideline. J Clin Endocrinol Metab 99:3933-3951, 2014.

16) Kobayashi T, Kida Y, Mori $Y$ : Gamma knife radiosurgery in the treatment of Cushing disease: long-term results. $J$ Neurosurg 97 (5 Suppl) : 422-428, 2002.

17) Kobayashi T, Mori Y, Uchiyama Y, Kida Y, Fujitani S : Lomgterm results of gamma knife surgery for growth hormoneproducing pituitary adenoma: is the disease difficult to cure? J Neurosurg 102 Suppl : 119-123, 2005.

18）厚生労働科学研究費補助金難治性疾患克服研究事業 間 脳下垂体機能障害に関する調査研究班：クッシング病診 断の手引き (平成 21 年度改訂). http://square.umin.ac.jp/ kasuitai/guidance/cushing.pdf（閲覧日：2018 年 1月）

19）厚生労働科学研究費補助金難治性疾患克服研究事業 間 脳下垂体機能障害に関する調査研究班：プロラクチン (PRL) 分泌過剩症の診断と治療の手引き (平成 22 年度 改訂). http://square.umin.ac.jp/kasuitai/guidance/prolactin surplus.pdf（閲覧日：2018 年 1 月）

20）厚生労働科学研究費補助金難治性疾患克服研究事業 間 脳下垂体機能障害に関する調査研究班：先端巨大症およ び下垂体巨人症の診断と治療の手引き（平成 26 年度改 訂).

21) Kurosaki M, Kambe A, Watanabe T, Fujii S, Ogawa T : Serial $3 \mathrm{~T}$ magnetic resonance imaging during cabergoline treatment of macroprolactinomas. Neurol Res $\quad 37: 341-346$, 2015.

22) Leber KA, Berglöeff J, Pendl G : Dose-response tolerance of the visual pathways and cranial nerves of the cavernous

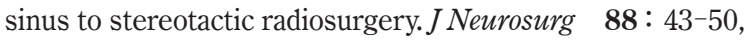
1998.

23) Melmed S : Medical progress : acromegaly. $N$ Engl J Med $355: 2558-2573,2006$.

24) Melmed S, Casanueva FF, Hoffman AR, Kleinberg DL, Montori VM, Schlechte JA, Wass JA : Diagnosis and treatment of hyperprolactinemia : an Endocrine Society clinical practice guideline. J Clin Endocrinol Metab 96 : 273-288, 2011.

25) Mete O, Grossman A, Trouillas J, Yamada S : Corticotroph adenoma. in Hoyd RV, Osamura RY, Kloppel G, Rosai J (eds) : WHO Classification of Tumours of Endocrine Organs 4th Edition. Lyon, IARC Publications, 2017.

26) Nieman LK, Biller BM, Findling JW, Murad MH, NewellPrice J, Savage MO, Tabarin A ; Endocrine Society: Treatment of Cushing's syndrome: an Endocrine Society clinical practice guideline. J Clin Endocrinol Metab $\quad 100: 2807-$ 2831, 2015.

27) Nishioka H, Fukuhara N, Horiguchi K, Yamada S : Aggressive transsphenoidal resection of tumors invading the cavernous sinus in patients with acromegaly: predicitive factors, strategies, and outcomes. J Neurosurg 121:505-510, 2014.

28) Nomikos P, Buchfelder M, Fahlbusch $R$ : The outcome of surgery in 668 patients with acromegaly using current criteria of biochemical 'cure'. Eur J Endocrinol 152:379-387, 2005.

29）沖 隆：Cushing 病。平田結喜緒，山田正三，成瀬光栄， 沖 隆, 高橋 裕編: 下垂体疾患診療マニュアル 改訂 第 2 版。東京，診断と治療社，2012，pp.156-162.

30) Oldfield EH, Vortmeyer AO : Development of a histological pseudocapsule and its use as a surgical capsule in the excision of pituitary tumors. J Neurosurg 104:7-19, 2006.

31) Ono M, Miki N, Kawamata T, Makino R, Amano K, Seki T, Kubo T, Hori T, Takano K : Prospective study of high-dose cabergoline treatment of prolactinomas in 150 patients. $J$ Clin Endocrinol Metab 93 : 4721-4727, 2008.

32) Ono M, Miki N, Amano K, Kawamata T, Seki T, Makino R, Takano K, Izumi S, Okada Y, Hori T : Individualized highdose cabergoline therapy for hyperprolactinemic infertility in women with micro- and macroprolactinomas. $J$ Clin Endocrinol Metab 95:2672-2679, 2010.

33) Phan K, Xu J, Reddy R, Kalakoti P, Nanda A, Fairhall J : Endoscopic endonasal versus microsurgical transsphenoidal approach for growth hormone-secreting pituitary adenomas - systematic review and meta-analysis. World Neurosurg 97 : 398-406, 2017.

34) Pollock BE, Jacob JT, Brown PD, Nippoldt TB : Radiosurgery of growth hormone-producing pituitary adenomas : factors associated with biochemical remission. J Neurosurg 106 : 833-838, 2007.

35) Puig Domingo $M$ : Treatment of acromegaly in the era of personalized and predictive medicine. Clin Endocrinol (Oxf) $83: 3-14,2015$

36) Schade R, Andersohn F, Suissa S, Haverkamp W, Garbe E : Dopamine agonists and the risk of cardiac-valve regurgitation. N Engl J Med $356: 29-38,2007$.

37) Stafford SL, Pollock BE, Foote RL, Link MJ, Gorman DA, Schomberg PJ, Leavitt JA : Meningioma radiosurgery : tumor control, outcomes, and complications among $190 \mathrm{con}-$ secutive patients. Neurosurgery $\quad 49: 1029-1037,2001$.

38) Starke RM, Raper DM, Payne SC, Vance ML, Oldfield EH, Jane JA Jr : Endoscopic vs microsurgical transsphenoidal surgery for acromegaly : outcomes in a concurrent series of patients using modern criteria for remission. J Clin Endocrinol Metab 98: 3190-3198, 2013.

39）高橋 裕：先端巨大症。平田結喜緒，山田正三，成瀬光 栄，沖 隆，高橋 裕編：下垂体疾患診療マニュアル 改訂第 2 版。東京，診断と治療社，2012，pp.132-135.

40) Teramoto A, Yoshida Y, Sanno N, Nemoto S : Cavernous sinus sampling in patients with adrenocorticotrophic hormone-dependent Cushing's syndrome with emphasis on 
inter- and intracavernous adrenocorticotrophic hormone gradients.J Neurosurg $\mathbf{8 9 : 7 6 2 - 7 6 8 , 1 9 9 8 .}$

41) Tishler RB, Loeffler JS, Lunsford LD, Duma C, Alexander E 3rd, Kooy HM, Flickinger JC : Tolerance of cranial nerves of the cavernous sinus to radiosurgery. Int J Radiat Oncol Biol
Phys 27:215-221, 1993.

42) Tritos NA, Biller BK: Update on radiation therapy in patients with Cushing's disease. Pituitary 18:263-268, 2015.

要

旨

機能性下垂体腺腫の治療

黒㟝 雅道

機能性腺腫の治療法としては手術，薬物，放射線治療があるが，手術方法としては，経蝶形骨洞的 下垂体腺腫摘出術（TSS）が一般に行われる. 最近では神経内視鏡を用いた TSS が多くの施設で採用 されている.

1) GH 産生腺腫（巨人症 ·先端巨大症)治療の第一選択は TSS である. 術後の治癒基準は厳格で あり, 臨床的活動性を示す徵候がまったくなく, ブドウ糖 $75 \mathrm{~g}$ 経口投与後の血中 $\mathrm{GH}$ 底值が $0.4 \mathrm{ng} /$ $\mathrm{m} /$ 末満, かつ IGF-1 值が年齢・性別基準範囲内であることが求められる. これを満たさないコント ロール不十分, 不良例に対しては, 薬物療法やガンマナイフを中心とした定位的放射線治療が行われ る. 薬物療法ではドパミン作動薬, ソマトスタチン誘導体, GH 受容体拮抗薬が用いられる.

2 ) PRL 産生腺腫 ドパミン作動薬の中でもカベルゴリンを用いた薬物療法が第一選択であり, 大 半の症例で PRL 值の正常化と腫瘍体積の減少がもたらされるが, 䯣液鼻漏（髄膜炎）をきたす可能性 があることに注意する. カベルゴリンを高用量使用することにより, ブロモクリプチン抵抗症例でも 良好な成績が得られるという報告もある. ドパミン作動薬服用中に妊娠が判明した場合にはただちに 中止するが, macroadenoma では増大傾向があるため, 定期的な視機能評価などの注意深い観察が必 要である.

3 ） ACTH 産生腺腫（Cushing 病） 治療に関しては TSS が第一選択であるが，小さな腺腫では局 在診断が困難なため海綿静脈洞からの血液サンプリングが有用とされている. 薬物療法に関しては, あまり有効なものがない. 治療困難例では, ガンマナイフを中心とした定位的放射線治療が有用であ る. 